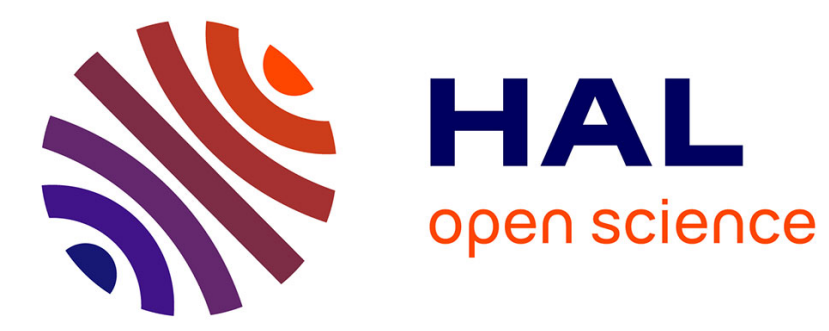

\title{
Stability of plant communities along a tropical inselberg ecotone in French Guiana (South America)
}

Corinne Sarthou, Denis Larpin, Emile Fonty, Sandrine Pavoine, Jean-François Ponge

\section{- To cite this version:}

Corinne Sarthou, Denis Larpin, Emile Fonty, Sandrine Pavoine, Jean-François Ponge. Stability of plant communities along a tropical inselberg ecotone in French Guiana (South America). Flora, 2010, 205 (10), pp.682-694. 10.1016/j.flora.2010.04.005 . hal-00519726

\author{
HAL Id: hal-00519726 \\ https://hal.science/hal-00519726
}

Submitted on 21 Sep 2010

HAL is a multi-disciplinary open access archive for the deposit and dissemination of scientific research documents, whether they are published or not. The documents may come from teaching and research institutions in France or abroad, or from public or private research centers.
L'archive ouverte pluridisciplinaire HAL, est destinée au dépôt et à la diffusion de documents scientifiques de niveau recherche, publiés ou non, émanant des établissements d'enseignement et de recherche français ou étrangers, des laboratoires publics ou privés. 


\section{Stability of plant communities along a tropical inselberg ecotone in French Guiana (South America)}

Corinne Sarthou ${ }^{1}$, Denis Larpin ${ }^{2}$, Émile Fonty ${ }^{3}$, Sandrine Pavoine ${ }^{4}$, Jean-François Ponge ${ }^{3 *}$

${ }^{1}$ Muséum National d'Histoire Naturelle, Département Systématique et Évolution, CNRS UMR 7205, 16 rue Buffon, Case Postale 39, 75231 Paris Cedex 05, France

${ }^{2}$ Muséum National d'Histoire Naturelle, Département des Jardins Botaniques et Zoologiques, Case postale 45, 43 rue Buffon, 75005 Paris, France

${ }^{3}$ Muséum National d'Histoire Naturelle, Département Écologie et Gestion de la Biodiversité, CNRS UMR 7179, 4 avenue du Petit-Château, 91800 Brunoy, France; e-mail ponge@mnhn.fr

${ }^{4}$ Muséum National d'Histoire Naturelle, Département Écologie et Gestion de la Biodiversité, CNRS UMR 5173, Case Postale 51, 55 rue Buffon, 75005 Paris, France

* Corresponding author

E-mail addresses of the authors:

C. Sarthou: sarthou@mnhn.fr

D. Larpin: larpin@mnhn.fr

E. Fonty: emile.fonty@ free.fr

S. Pavoine: pavoine@mnhn.fr

J.F. Ponge: ponge@mnhn.fr 


\section{Abstract}

We questioned whether and how plant communities vary in space and time along an inselbergrainforest ecotone in relation to present-day warming and whether biotic and non-biotic factors could explain the observed patterns. The study took place on a granitic inselberg in the French Guianan (South America) rainforest (Nouragues Natural Reserve: $\left.4^{\circ} 5^{\prime} \mathrm{N}, 52^{\circ} 41^{\prime} \mathrm{W}\right)$. In a diachronic study (1995-2005) embracing a severe El-Niño event in 1997, we analysed vegetation structure and composition along three transects subsuming whole environmental and topographical variations in the transition zone from shrub vegetation at the fringe of open-rock vegetation to tall-tree rainforest. Data were analysed by PCA. Major variations in species and trait distribution were described in the low forest, with two floristic types evidenced by first PCA component and verified by cluster analysis: one with floristic composition reminiscent of open-rock vegetation but with higher and continuous canopy, the other typical of the low forest. There is no clear-cut boundary between typical open-rock and low forest vegetation. Variation in species composition of typical low forest was evidenced by second PCA component, which displayed differences according to slope and altitude. Small $(\sim 1.5 \mathrm{~m})$, although significant, shifts in the spatial distribution of plant species pointed to possible slow encroachment of typical low forest vegetation in the absence of disturbance. However, the stability of species and trait distribution was remarkable within the 10-yr interval considered, despite an otherwise recorded decrease in species richness and recruitment. The boundary between typical low forest and open-rock-like vegetation coincided with the spatial limit of the mineral soil above granite. Despite demographic accidents due to severe El Niño events, plant communities at the fringe of a tropical inselberg are stable at short-time both in composition and spatial distribution. In the absence of strong disturbances such as wildfire and further erosion, soil availability for roots could be interpreted as an environmental constraint to the successional development of forest vegetation. Soil development might thus act as an ecological barrier to forest encroachment, which could only be alleviated by erosion recovery, as otherwise demonstrated.

Keywords: Inselberg; French Guiana; Ecotone; Plant communities; Low forest; Open-rock vegetation; Diachronic change; Ecological barrier 


\section{Introduction}

Ecotones, as 'zones of transition between adjacent ecological systems', have long time fascinated ecologists (synthesis in Hansen and Di Castri, 1992) and challenged them to find causes and resulting patterns. Such discontinuities in vegetation composition may offer insights into the factors controlling the assembly of plant communities and thus may have significance for management and nature conservation. Main effects of environmental change are likely to be seen first at ecotones due to physiological characteristics of species occurring there (Neilson, 1991; Kupfer and Cairns, 1996; Allen and Breshears, 1998).

Many studies reported discrete vegetation boundaries on tropical mountains (e.g. Woldu et al., 1989; Kitayama, 1992; Kitayama and Mueller-Dombois, 1994; Fernandez-Palacios and de Nicolas, 1995; Kitayama, 1995; Ashton, 2003; Hemp, 2005; Martin et al., 2007; Sherman et al., 2008). Robust quantitative studies of compositional distribution that could address global change require highly replicated, fine-scale sampling (e.g. Vazquez and Givnish, 1998), but such studies are rare in the tropics, primarily because of the large sampling area needed for species census in species-rich tropical plant communities.

Inselbergs, from German 'insel' for island and 'berg' for mountain (Bornhardt, 1900), shaping isolated hills or groups of hills, constitute a peculiar model of mountain environment. In tropical areas, these frequently huge, Gyr-old monoliths mainly consist of Precambrian granites or gneisses and are defined as remnants of erosion processes within a plain landscape (Cooke et al., 1993). They form 'xeric islands' within a rain forest matrix and harbour unique open-rock vegetation enduring harsh edaphic and microclimatic conditions. Floristic studies carried out on tropical inselbergs have been synthesised by Porembski and Barthlott (2000). Since this synthesis, other surveys dealing with inselberg vegetation have been mainly concerned with description of plant communities (Parmentier et al., 2001; Oumorou and Lejoly, 2003; Sarthou et al., 2003; Parmentier et al., 2005; Parmentier and Müller, 2006). Monocotyledonous mats, small grasslands and shrub thickets characterise the outcrop vegetation of inselbergs, but ecotones, i.e. transition areas between xerophilous outcrop vegetation and rainforest, have been rarely studied (Parmentier et al., 
2005) and diachronic studies have never been conducted on tropical inselbergs. However, boundaries between such contrasted environments might allow study cases of directional changes in species and species trait distribution in the perspective of global warming, as this has been done at the upper forest limit in tropical mountains (Vázquez and Givnish, 1998; Ashton, 2003; Hemp, 2005, 2006; Martin et al., 2007) and in forestgrassland or forest-scrub tropical and sub-tropical ecotones (Allen and Breshears, 1998; Grau and Veblen, 2000; Favier et al., 2004).

In French Guiana, a granitic inselberg located in the Nouragues Biological Reserve has been particularly studied since two decades. Three ecosystems with genuine plant communities have been studied: open-rock vegetation (locally called 'savane-roche'), low forest and tall-tree rainforest, the two latter being closed habitats. The two former vegetation types and specially epilithic plant communities have been described extensively (Sarthou, 1992; Larpin, 1993; Sarthou and Villiers, 1998; Sarthou, 2001; Larpin, 2001; Sarthou et al., 2003). They are characterized by highly contrasted ecological conditions. In open-rock vegetation, exposed rocks are subject to high levels of insolation in combination with high evaporation rates. Shallow soils and steep slopes cause a rapid run-off of water. Organic matter and roots accumulate locally under shrub thickets (Kounda-Kiki et al., 2006, 2008). In the low forest, the temperature is more buffered and soils are deeper and mostly made of mineral matter overlaid by a thin litter layer. Both ecosystems were submitted to occasional fires during past dry periods as demonstrated by charcoal layers in the soil (CharlesDominique et al., 2001; Kounda-Kiki et al., 2008) and past erosive sequences (Rosique et al., 2000). Whether of natural or human origin, fires dated from 10,000 to $100 \mathrm{yr}$ BP are a driving force of vegetation dynamics. It is currently admitted that Guianan inselbergs, between severe and widespread fire events associated with colder and drier periods, are invaded by forest communities (de Granville, 1982; Ledru et al., 1997; CharlesDominique et al., 1998; Larpin et al., 2000; Charles-Dominique et al., 2000, 2001).

However, the continuum from the fringe of open rock vegetation to the rainforest remains rather unknown. In a previous paper, we reported a marked decrease in plant species richness and tree recruitment in a 10-yr period (1995-2005) embracing a severe El-Niño event in 1997 (Fonty et al., 2009). In the present study, we explored the community scale and questioned the temporal change of the vegetation on the ecotone 
gradient over the same period. This is the first diachronic study of plant communities along a tropical inselberg ecotone in South America and we address the following questions (1) do present-day environmental conditions explain the spatial distribution of plant species in the contact zone between low forest and shrub vegetation fringes on rock outcrops? (2) did this distribution change during the recorded time lag?

\section{Methods}

\section{Study site}

Our study was conducted in French Guiana on a granitic inselberg 410m high in the Nouragues Natural Reserve $\left(4^{\circ} 5^{\prime} \mathrm{N}, 52^{\circ} 41^{\prime} \mathrm{W}\right)$ in South America. The climate in the study area is seasonal, with a long rainy season from December to June and a short drier season from August to November. Annual precipitation averages $4000 \mathrm{~mm}$. Mean annual air temperature lies between 25 and $27^{\circ} \mathrm{C}$ at the Nouragues station (Grimaldi and Riéra, 2001). Climatic measurements (synthesis in Fonty et al., 2009) indicate a marked El Niño event in 1997. This granitic whaleback dome protruding $\sim 300 \mathrm{~m}$ from the rain forest matrix (Fig. 1) belongs to continental sets of rocks that constitute the base of the Guiana Shield extending north to Amazon River from Venezuela to Colombia (Théveniaut and Delor, 2004). Whenever the slope becomes too steep, differential erosion tends to increase more and more the slope, locally impeding forest settlement. This is the origin of present-day inselbergs. The topography is rugged, with steep slopes.

Open-rock vegetation is characterized by a discontinuous plant cover, separated by exposed rock, at the top and on southern and eastern sides of the inselberg (Figs. 1 and 2). This xerophilous vegetation is composed of numerous small scattered patches of epilithic wind- and bird-disseminated herb species and shrubs. Two widespread plant communities give a typical aspect to the landscape (Sarthou, 2001): a herbaceous community dominated by the bromeliad Pitcairnia geyskesii established directly on granite and a shrub community dominated by the Clusiaceae Clusia minor forming thickets 2-8 m tall, with an organic soil (Kounda-Kiki et al., 2006). Thickets in the contact zone with the low forest are likely denser and more diversified (Sarthou, 1992, 2001). Measurements of air temperature and relative air humidity show high 
diurnal variations (Sarthou, 1992, 2001; Rascher et al., 2003). Due to shallow soils with a low water-holding capacity, moisture conditions in this ecosystem are harsher than everywhere on the inselberg (Sarthou and Grimaldi 1992).

The low forest surrounds open-rock vegetation, forming a transition zone with the tall-tree rainforest, and is also established on the summit of the inselberg (Figs. 1 and 2). In contrast with open-rock vegetation, the amplitude of temperature and moisture variations is much lesser, even during the dry season (Larpin, 1993, 2001). Enrichment in water and nutrients by inflow from above located open-rock vegetation (Sarthou and Grimaldi, 1992; Dojani et al., 2007) gives to the vegetation of the low forest a lush, species-rich aspect, with many epiphytes and terricolous herbs in the understory along with a diversity of shrubs and small trees (Larpin, 1993, 2001). This vegetation has been described as a specific community characterized by Myrtaceae. Prominent features of the low forest are: low canopy $(<10 \mathrm{~m})$, multi-stemming and vertical stratification of the vegetation (Fig. 2). Woody species are usually zoochorous and mainly dispersed by small birds (Larpin 2001). Soils are of varying depth $(0-180 \mathrm{~cm})$, increasing in depth from open-rock vegetation to the tall-tree rainforest (Fig. 2).

The tall-tree rainforest hosts a great diversity of trees, the height of which averages 30-35 m with emergent trees reaching $50 \mathrm{~m}$ in height (Poncy et al., 2001). Soils are acid $(\mathrm{pH}<5)$ clay-sandy Ferralsols (FAO, 2006) with a micro-aggregate organo-mineral texture of biological origin (Pouvelle et al., 2008) and a sparsely distributed litter cover (Grimaldi and Riéra 2001). Treefall gaps and erosive processes take a prominent part in the dynamics of vegetation (Riéra, 1995; Sabatier et al., 1997).

Fires, whether of human or natural origin, affect the fate of vegetation and open cues to strong erosive processes (Sabatier et al., 1997; Rosique et al., 2000). Open as well as forested sites were submitted to occasional fires during past dry periods as demonstrated by charcoal layers in the soil (Charles-Dominique et al., 2001; Kounda-Kiki et al., 2008). The general disappearance of the original Amerindians at the end of the 18th century let this place devoid of permanent human occupation since about two centuries (Hurault, 1972). 


\section{Sampling}

Three transects T4, T5 and T6 were established on southern, eastern and summit positions, respectively (Fig.1). Transect length reached $89 \mathrm{~m}, 65 \mathrm{~m}$ and $52 \mathrm{~m}$, respectively. All transects started on bare rock at the boundary of open-rock vegetation, going into the forest and stopped when the tall trees that characterize the rain forest first appeared (Fig. 2). They overwhelmed the whole area of what was described as the low forest by Larpin $(1993,2001)$. These transects were chosen in order to describe the whole range of topographical conditions prevailing on the inselberg. Transect T4 showed an average 38\% slope and was at $130 \mathrm{~m}$ mid elevation. Transect T5 showed an average 24\% slope and was at $100 \mathrm{~m}$ mid elevation. Transect T6 showed an average $2 \%$ slope and was at $380 \mathrm{~m}$ mid elevation.

Vascular plants were identified to species or genus at the "Herbier de Guyane" in Cayenne and updated with a checklist by Funk et al. (2007). Census was taken each metre on adjacent quadrats (1x2 m). In each plot, the diameter of each stem was measured to the next $\mathrm{cm}$, the canopy height was estimated visually and the number of individuals per quadrat was counted for every species. In case of multi-stemming, stems were pooled at the individual level for the calculation of species abundance per quadrat. The cover percentage of herbs and suffrutex species was estimated visually in each quadrat to the next $5 \%$. The three transects were sampled again in April 2005 (same month and same rainy conditions as in 1995), after thorough examination of previous maps and retrieval of keystone trees which were used for replacing transects at the exact position they occupied 10 years sooner. The same well-trained botanists (D. Larpin and C. Sarthou) were present on the field in 1995 and 2005, thus avoiding biases in cover percentage estimates underlined by Leps and Hadincova (1992). The soil depth (organic and mineral) was measured in 2005 only, by forcing a 1-m steel post in the soil with a hammer, until the granite substrate was attained when not deeper than $70 \mathrm{~cm}$.

\section{Data processing}

Vegetation data (number of individuals for woody species, percent cover for herbs and suffrutex species, in each quadrat and each transect) were analysed by Principal Components Analysis (PCA), using 
only species which were present in at least 10 quadrats over all transects and both years. Elevation, slope, depth of organic layer and mineral soil and year were added as passive variables in PCA and were projected on factorial scatter plots without having any influence on the calculation of factorial axes, also called principal components (indirect gradient analysis). All variables were standardized (mean 0 , standard deviation 1), thus allowing data of different kinds and scales to be included in the same multivariate analysis, using correlation coefficient values in place of Euclidean distances (Chae and Warde, 2006). The choice of indirect rather than direct (RDA, DCA) gradient analysis was justified by the need to allow patterns merge from the data without any a priori hypotheses about the distribution of plant species and changes which could occur in the course of time. The choice of PCA over CoA (correspondence analysis) was justified by the nature of the data, which varied from occurrence data (for woody species) to cover percentages (for herbs and suffrutex species). The distribution of plant traits (life forms, fruit and dispersal types, functional types, seed sizes) was graphically studied in F1-F2 species scatter plots.

Cluster analysis (Legendre and Legendre, 1998) was performed on plant species using hierarchical aggregative average-linkage clustering with Spearman rank correlation coefficients of raw data (used for PCA) as between-species similarity measurement.

Given that sampling was done along transect lines across variable environments, autocorrelation was expected (Legendre and Legendre, 1998). Correlations between species richness, canopy height (a surrogate of forest development), soil depth and Principal Component 1 of PCA (a surrogate of shift from open-rock to forest vegetation, as explained below) were analysed by simple or partial Mantel tests, the latter using distance along transects as co-variate (Legendre and Legendre, 1998). We used signed Mantel tests, in which the distance between two samples (quadrats) was estimated by the signed difference between corresponding values of the studied factor (Oberrath and Böhning-Gaese, 2001). The significance of Mantel tests was tested by Monte-Carlo simulation procedure (5,000 runs).

To each plant species was assigned a mean distance from transect start, which was calculated by weighing all distances (from meter to meter) by abundance (for trees and shrubs) or cover percentage (for 
herbs and suffrutex species) and averaging these values over a whole transect, in 1995 and in 2005. Species were classified in groups (all species, trees and shrubs, herbs and suffrutex species) the mean values of which were compared in 1995 and 2005 by paired t-test, using species as independent replicates.

All abovementioned calculations were done using XLSTAT statistical software (AddinSoft, 2009).

Variation in the distribution of plant species between 1995 and 2005 was tested by co-inertia analysis (Dolédec and Chessel, 1994) followed by Monte-Carlo test. The meaningfulness of species groups depicted by PCA was verified by two-way bottom-up hierarchical cluster analysis using Euclidean distances between coordinates of plant species along the first five factorial axes of PCA, with Bonferroni adjustment and Ward's criterion (variance increase) for aggregation (Dray, 2008). These analyses are implemented in the $\mathrm{R}$ programme (Ihaka and Gentleman, 1996).

\section{Results}

A total of 150 plant species were found in the three studied transects over both years 1995 and 2005. They were comprised of 109 tree and shrub species (Appendix 1) and 41 herb and suffrutex species (Appendix 2), most of them being determined at the species (69\%), genus (81\%) or family level (95\%). Among woody species, Myrtaceae were the dominant family (20 species), followed by Rubiaceae (10 species). Among herbs and suffrutex species, Bromelieaceae were the dominant family (8 species), followed by Poaceae (8 species) and Orchidaceae (6 species).

\section{The state of change of the plant community}

A concomitant increase in local species richness (number of plant species per quadrat) and canopy height (height of tallest woody stems per quadrat) was observed along the three transects (Table 1). Whatever transects were considered, species richness and canopy height exhibited a highly significant positive correlation, which remained positive and highly significant when correcting for spatial influence. At the start 
of each transect, at the boundary of open-rock vegetation, the species richness was very low (1 to 3 species per quadrat) while it reached 25 to 30 species per quadrat at the boundary of the tall-tree rain forest (transect end). The canopy height rose from 0 at transect start to 10 to $30 \mathrm{~m}$ (according to transects), in the forest. Despite a general increasing trend of canopy height, a great variation was observed in Transects 4 and 5 . Transect 4 (established on steep slope) exhibited several collapses in species richness, which can be explained by local wind-throws (treefall gaps) between 1995 and 2005.

The projection of 410 samples and five passive variables (elevation, slope, year, depth organic, depth mineral) in the F1-F2 bi-plot of PCA (Fig. 3a) showed that the year effect was negligible compared to that of depth of mineral soil (highly correlated with the first component F1, which extracted $7.2 \%$ of the total variation), and that of elevation and slope (both highly correlated with the second component F2, which extracted $5.5 \%$ of the total variation). In $\mathrm{T} 4, \mathrm{~T} 5$ and $\mathrm{T} 6$ and in both years, quadrats were projected on both positive and negative sides of F1, with a clear discontinuity between two groups of quadrats in T4 and T6 (Fig. 3b). The first component was correlated with the depth of mineral soil above the granitic substrate, as indicated by a highly significant Mantel correlation coefficient (Table 1), which remained significant when spatial effects were discarded. The distribution of F1 values along the three transects showed a strong spatial dependence (Fig. 4): at start of transects, F1 values were negative and increased towards positive values with distance. Positive values of F1 were clearly associated with the presence of a mineral soil. It can be seen on T4 that each 'accident' in the depth of the mineral soil (granite apparent or only covered with an organic layer) was associated with a reversal towards negative values of F1. The passage from negative to positive values of F1 was progressive in T5 but rather abrupt in T4 and T6.

The second principal component F2 separated T4 and T5 (lower elevation and higher slope) from T6 (higher elevation and lower slope). This separation concerned mainly samples far from transect start, i.e. those where mineral soil was present and with positive F1 coordinates (Fig. 4). Differences between years were not very pronounced (Figs. 3 and 4), except that positive F1 coordinates were for the main higher in 1995 than in 2005, the contrary being shown on the negative side. As a result, the variance of F1 values was higher (9.0) in 1995 than in 2005 (5.3). 
The projection of plant species in the F1-F2 scatter plot showed three groups of plant species, corresponding to three branches in the cloud of data (Fig. 5a). A species group was projected on the negative side of F1, while species with positive F1 values were separated in two groups by F2. Primary cluster analysis (Fig. 6) displayed a clear dichotomy between two main groups of species which were nearly identical to the two groups separated along the first component of PCA. A total of 28 among the 30 species classified in the first cluster (Community I) had negative values for F1, the other two species (Bromelia $s p .1$ and Inga umbellifera) having positive values for F1 but not far from zero (Fig. 5). Conversely, a total of 49 among the 51 species classified in the second cluster (Community II) had positive values for F1, the other two species (Syagrus stratincola and Poacaeae sp. 4) having negative values for F1 but not far from zero (Fig. 5). The two-branch dichotomy which was observed along the second principal component of PCA was not retrieved by cluster analysis (Fig. 6).

Herbs and suffrutex species represented $50 \%$ of the species in Community I (Fig. 5b), belonging mainly to Bromeliaceae and Cyclanthaceae and with a high cover for Stelestylis surinamensis. Herbs and suffrutex species were poorly represented in Community II, comprising less than $2 \%$ of the species (Fig. 5 b), and were mainly composed of Poaceae. The dominant families of woody plants in Community I were Myrtaceae (Myrcia saxatilis, M. guianensis, Eugenia florida, Myrciaria sp2), Clusiaceae (Clusia minor, C. nemorosa) and Melastomataceae (Ernestia granvillei, Miconia ciliata). Community II was characterized by 40 tree and shrub species belonging mainly to Myrtaceae (22.5\%), Rubiaceae (15\%), Mimosaceae (7.5\%), Erythroxylaceae (5\%) and Apocynaceae (5\%) (Appendices 1 and 2). The floristic composition exhibited an abrupt change from Community I to Community II along T4 and T6 and a continuum in T5 (Fig. 4).

The second principal component of PCA expressed changes in the species composition of Community II which occurred according to the position of transects on the inselberg (Figs. 3 and 5). This result points to the existence of sub-communities within Community II, which are separated by their position around the inselberg. However, cluster analysis did not display the existence of clear sub-groups of plant species within the second cluster (corresponding to positive F1 values), the stemming of branches being 
continuous within each of the two clusters corresponding to Community I and Community II, respectively.

Year (1995 vs 2005) did not influence to a great extent the distribution of plant species in the F1-F2 scatter plot. The absence of any significant variation in the distribution of plant species between 1995 and 2005 was verified by co-inertia analysis on T4, T5 and T6: both matrices (1995 and 2005) were positively correlated $(\mathrm{r}=0.79, \mathrm{P}=0.001)$. However, it can be observed that positive $\mathrm{F} 1$ coordinates were in the main higher in 1995 than in 2005, the contrary being shown on the negative side (Figs. 3 and 4). As a result, the variance of F1 values was higher (9.0) in 1995 than in 2005 (5.3). It must be noted, too, that the alternation of humps and mounds depicted by F1 values along each of the three transect lines (Fig. 4) showed a good correspondence between 1995 and 2005, which validated transect positioning ten years after the first installation.

Species traits were not equally distributed on both sides of F1, corresponding to the two abovementioned plant communities. In addition to the already reported habitat preference of herbs and suffrutex species for lower parts of transects (corresponding to the first cluster of cluster analysis or Community I), lianas (5 species kept for PCA) were all projected on the positive side of F1 (Fig. 5). This was also the case for trees, to the exception of one species (Humiria balsamifera). Apart from this exception, all woody species belonging to Community II were shrubs. Most plants with berries (16 among 24) and drupes (10 among 13) were projected on the positive side of F1, whereas most species having capsules (14 among 20) were projected on its negative side. However, plants with achenes (4 species) were distributed equally on both sides of F1, indicating the absence of any preference for the two communities. Other fruit types were negligible. In accordance with fruit types, dispersal types showed a discrepancy between both communities, anemochorous species belonging mostly to Community I (15 among 24) while zoochorous species belonged mostly to Community II (38 among 50), the other dispersal types being poorly represented (Fig. 5). With exception of climbing plants (lianas), which were only represented in Community II, other functional types did not show any pronounced preference for one or the other community. Small seeds $(<0.5 \mathrm{~cm})$ were mostly present in Community I (18 among 30) but most discrepancy occurred with large seeds $(>1 \mathrm{~cm})$ which, to the exception of Tabebuia capitata, belonged to Community II, while medium-sized seeds were present in similar 
proportions in both communities. Thus the first component of PCA depicted also a gradient of species traits, from a herb/suffrutex/shrub community characterized by dry fruits with small to medium seeds disseminated by wind to a tree community (with lianas) characterized by fleshy fruits with medium to large seeds disseminated by animals.

Further axes of PCA were neglected, since they displayed only very minor changes in floristic composition, not explained by environmental factors, and which were not validated by cluster analysis.

\section{Community boundaries and their shifts from 1995 to 2005}

New sampling done in 2005 did not reveal any pronounced displacement in the passage from one community to another, which occurred roughly at the same position on the transect lines. On both years, Community I was replaced by Community II once the mineral soil appeared (Fig. 4). Mantel tests showed that the first principal component of PCA for samples (F1) was positively correlated with depth of the mineral soil, and that this correlation remained positive and highly significant $(\mathrm{P}<0.0002)$ when the effect of distance

was eliminated (Table 1). However, the mean distance of plant species from the start of Transects 4, 5 and 6 varied to a weak ( 1.5 m) but significant extent from 1995 to 2005 (Table 2): in average, there was a weak displacement of plant species along transects in the direction of the open environment, whatever their growth habit.

\section{Discussion}

\section{Ecological determinants of plant assemblages}

The ordination of vegetation samples by indirect gradient analysis (PCA) displayed the existence of two distinct communities within the low forest. Community I resembled, by its floristic composition although not by its physiognomony, the open-rock vegetation ('savane-roche') described by Sarthou (1992, 2001), Sarthou and Villiers (1998) and Sarthou et al. (2003) as a mosaic of epilithic herbaceous and shrub 
communities involved in a successional process (Sarthou, 1992; Sarthou et al., 2009). According to observations by Sarthou (1992) shrub thickets dominated by Clusia minor and several Myrtaceae increase in height and density ('border thickets') as far as open-rock vegetation stems in the continuous canopy cover typical of the low forest. Therefore it seems that there is no clear-cut boundary between typical open-rock vegetation and the part of the low forest which we called Community I. As in open-rock vegetation this shrub community is established on accumulated organic matter (5 to $20-30 \mathrm{~cm}$ ) without mineral soil. Humus forms resemble those described by Kounda-Kiki et al. $(2006,2008)$ under open-rock vegetation. Our transect analysis suggests that species typical of the low forest according to Larpin $(1993,2001)$ pertain to Community II, with a continuum (T5) or a discontinuity (T4, T6) in the variation of the floristic composition, according to the distribution of the mineral soil. This points to the presence of plant species representative of open-rock vegetation within what is commonly viewed on the field as the low forest, as this has been already noted by Larpin (1993, 2001). As ascertained from Figure 4, and according to Larpin (1993), this phenomenon is currently occurring each time granite boulders outcrop and mineral soil is absent. Separate analyses, performed on each transect, did not reveal any further subdivision within the low forest community.

Soil depth and soil carbon were also considered to be the main determinants of community shifts on other tropical outcrops in Africa (Parmentier et al., 2005; Parmentier and Müller, 2006) and Australia (Withers, 2000). Most detailed study on tropical inselberg ecotones was that of Parmentier et al. (2005). Using multivariate methods they showed on 27 inselbergs from Central Africa that at the local scale most pronounced changes in species and trait distribution occurred along the forest-open rock gradient, with a similar shift from prostrated to erected vegetation and corresponding life forms. However, their study, being not based on transects but rather on a wide array of dispersed samples, did not allow checking abrupt or continuous changes in floristic composition along ecotone gradients. Here we showed that contrasted situations may be observed on the same inselberg (Fig. 4): two transects (T4 and T6) showed an abrupt shift from Community I to Community II, while transect T5 showed a more continuous change in its floristic composition. This discrepancy cannot be explained by any variation in gradient length, given that in all cases soil conditions varied abruptly along transect lines (Fig. 4) and thus our results cannot exclude individualistic hypotheses of community structure (Connell, 1978; Vázquez and Givnish, 1998). 
The development of a tall and species-rich community on deeper mineral soils can be explained, not only by more space for the vertical extension of tree root systems (Poszwa et al., 2002), but also and more surely by the mineral soil acting as a sink for water flow and nutrients provided by mineral weathering and biological fixation (Dojani et al., 2007). This may explain, among other factors, the luxury of the typical low forest (in species as well as in individuals) compared to adjoining environments such as open-rock vegetation and tall-tree rainforest. Community II is the best representative of the species-rich typical low forest community which has been described by Larpin $(1993,2001)$ on the Nouragues inselberg and by other authors in other parts of the world (synthesis in Porembski and Barthlott, 2000). However, it seems that the distinction of a tree/shrub community, with strong floristic affinities with open-rock vegetation, has been overlooked in the absence of exhaustive sampling along large transect lines. Although epilithic, Community I, with its dense and closed canopy, seems to act as a buffer against destruction of the typical low forest (Community II) by storms and erosive events. This is reminiscent of the protection against hurricanes and wildfires which is offered by coniferous trees at tropical mountain tree-lines (Martin et al., 2007).

\section{Stability of plant assemblages}

The community composition did not change conspicuously in 10 years, pointing to stability of the forest fringe. However, the distance to the start of transects, always located in typical open-rock vegetation on granite, decreased to some extent for woody and to a lesser extent for non-woody plant species (Table 2). Given the importance of soil for forest development, which has been registered in successional studies on terraces (Viereck et al., 1993), we suspect that the time scale chosen for our new census of vegetation was too short for discerning neatly any common trend of soil and vegetation development, which should rest on centuries if not millenaries (Bremer and Sander, 2000). As a corollary, the absence of a mineral soil in parts of the inselberg covered by open-rock vegetation and in the distal part of the low forest can be considered as an environmental barrier for the forest community, thus explaining the contour of the forest ecosystem without any biological (Houle and Phillips, 1989) nor climatic (Sanz-Elorza et al., 2003) interference. It can be reasonably thought that the passage from xeric inselberg vegetation to rain forest vegetation is a time- 
consuming successional process, including progressive and slow succession, as this has been shown to occur on tropical rocky outcrops (Ibisch et al., 1995). Moderate disturbances such as wind-throws (single treefall gaps), which are often observed in the low forest (Larpin, 1993, 2001) and in the 'savane roche' (Sarthou, 1992, 2001) probably also contribute to explain local/temporary shifts in species richness, canopy height and community composition, such as those observed in our study (see Transect T4 in Figure 4). They may also contribute to explain the high species richness of the low forest according to the intermediate disturbance hypothesis (Sheil and Burslem, 2003). The rate at which forest vegetation is encroaching on the studied inselberg (1.5 m over 10-yr) does not offer any opportunity that forest vegetation would totally replace openrock vegetation between two fire periods according to data by Charles-Dominique et al. (1998). It may even be thought that present-day climate warming, and accompanying increased frequency of severe El Niño events in the Southern Oscillation Zone (Malhi and Wright 2004) cause a reversion of the successional progress. Results of a parallel study showed that the recruitment of juveniles of woody species between 1995 and 2005 was severely affected by the severe El-Niño event which occurred in 1997 (Fonty et al., 2009). In this study we observed a decrease of $24 \%$ for individuals and $22 \%$ for species over the 205 quadrats of the three transects (totalling $410 \mathrm{~m}^{2}$ ).

\section{About fire}

The role of fire cannot be neglected, but only if we consider it at the scale of centuries rather than of years. Lightnings are frequently observed to occur, more especially in open-rock vegetation, where they have been suspected to play a significant role in the renewal of vegetation thickets (Kounda-Kiki et al., 2008; Sarthou et al., 2009), but their impact rarely extend over a few meters. This is in marked contrast with studies done on other inselbergs and tropical mountain ecotones where human influence (associated or not with pastoralism) and present-day climate warming increase the risk of uncontrolled severe wildfires which destroy the ecotone and make it more abrupt and far below its natural level (Grau and Veblen, 2000; Parmentier et al., 2005; Hemp, 2005; Martin et al., 2007; Sherman et al., 2008). When tropical ecotones are protected from fire, then the often-reported sharp transition from forest to open environments is replaced by a gradual change quite similar to that observed in our study site (Allen and Breshears, 1998). 


\section{Conclusion}

On the Nouragues inselberg, two plant communities, called Community I (wind-dispersed shrubs, herbs and suffrutex species) and Community II (animal-dispersed shrubs and trees, with numerous Myrtaceae) were shown to compose what is currently known as the 'low forest', an ecotone between two strongly contrasted environments, open-rock vegetation ('savane roche') and tall-tree rainforest. The passage from one to the other community may be abrupt or progressive, according to cases, but is always related to soil development, Community I, which exhibit strong floristic affinities with open-rock vegetation, is established on a thick humus layer directly overlying the granitic substrate, while Community II displays a shallow mineral soil with a thin litter layer at the ground surface. Despite demographic accidents due to severe El Niño events, plant communities at the fringe of the Nouragues tropical inselberg are stable at shorttime both in composition and spatial distribution. In the absence of strong disturbances such as wildfire and further erosion, soil availability for roots could be interpreted as an environmental constraint to the successional development of forest vegetation. Soil development might thus act as an ecological barrier to forest encroachment, which could only be alleviated by erosion recovery, as otherwise demonstrated.

\section{Acknowledgements}

We want to acknowledge the staff of the Nouragues Research Station (CNRS UPS 656, dir. P. Charles-Dominique) for accommodation and technical help.

\section{References}

AddinSoft (2009). XLSTAT (data analysis software system), version 2009.4.03. AddinSoft, Paris.

Allen, C.D., Breshears, D.D., 1998. Drought-induced shift of a forest-woodland ecotone: rapid landscape response to climate variation. PNAS 95, 14839-14842. 
Ashton, P.S., 2003. Floristic zonation of tree communities on wet tropical mountains revisited. Persp. Plant Ecol. Evol. Syst. 6, 87-104.

Bornhardt, W., 1900. Zur Oberflächengestaltung und Geologie Deutsch-Ostafrikas. Reimer, Berlin.

Bremer, H., Sander, H., 2000. Inselbergs: geomorphology and geoecology. In: Porembski, S., Barthlott, W. (Eds.), Inselbergs: biotic diversity of isolated rock outcrops in tropical and temperate regions. Springer, Berlin, pp. 7-35.

Chae, S.S., Warde, W.D., 2006. Effect of using principal coordinates and principal components on retrieval of clusters. Comput. Stat. Data Anal. 50, 1407-1417.

Charles-Dominique, P., Absy, M.L., Larpin, D., Ledru, M.P., Riéra, B., Servant, M., Sarthou, C., Tardy, C., Turcq., B., 2000. Incidents climatiques et modifications de l'écosystème forestier depuis 3000 ans en Guyane française. In: Servant, M., Servant-Vildary, S. (Eds.), Dynamique à long terme des écosystèmes forestiers intertropicaux. UNESCO, Paris, pp. 71-76.

Charles-Dominique, P., Blanc, P., Larpin, D., Ledru, M.P., Riéra, B., Rosique, T., Sarthou, C., Servant, M., Tardy, C., 2001. Palaeoclimates and their consequences on forest composition. In: Bongers, F., Charles-Dominique, P., Forget, P.M., Théry, M. (Eds.), Nouragues: dynamics and plant-animal interactions in a neotropical rain forest. Kluwer, Dordrecht, pp. 35-44.

Charles-Dominique, P., Blanc, P., Larpin, D., Ledru, M.P., Riéra, B., Sarthou, C., Servant, M., Tardy, C., 1998. Forest perturbations and biodiversity during the last ten thousand years in French Guiana. Acta Oecol. 19, 295-302.

Connell, J.H., 1978. Diversity in tropical rain forests and coral reefs. Science 199, 1302-1310. 
Cooke, R.U., Warren, A., Goudie, A.S., 1993. Desert geomorphology. UCL Press, London.

Dojani, S., Lakatos, M., Rascher, U., Wanek, W., Lüttge, U., Büdel, B., 2007. Nitrogen input by cyanobacterial biofilms of an inselberg into a tropical rain forest in French Guiana. Flora 202, 521529.

Dolédec, S., Chessel, D., 1994. Co-inertia analysis: an alternative method for studying species-environment relationships. Freshwater Biol. 31, 277-294.

Dray, S., 2008. On the number of principal components: a test of dimensionality based on measurements of similarity between matrices. Comput. Stat. Data Anal. 52, 2228-2237.

Favier, C., Chave, J., Fabing, A., Schwartz, D., Dubois, M.A., 2004. Modelling forest-savanna mosaic dynamics in man-influenced environments: effects of fire, climate and soil heterogeneity. Ecol. Model. 171, 85-102.

Fernandez-Palacios, J.M., de Nicolas, J.P., 1995. Altitudinal pattern of vegetation variation on Tenerife. J. Veg. Sci. 2, 183-190.

Fonty, E., Sarthou, C., Larpin, D.; Ponge, J.F., 2009. A 10-year decrease in plant species richness on a neotropical inselberg: detrimental effects of global warming. Global Change Biol. 15, 2360-2374.

Funk, V., Hollowell, T., Berry, P., Kelloff, C., Alexander, S.N., 2007. Checklist of the plants of the Guiana Shield (Venezuela: Amazonas, Bolivar, Delta Amacuro; Guyana; Surinam; French Guiana). Contr. US Nat. Herbarium 55, 1-584.

de Granville, J.J., 1982. Rain forest and xeric flora refuges in French Guiana. In: Prance, G.T. (Ed.), 
Biological diversification in the tropics. Columbia University Press, New York, pp. 159-181.

Grau, H.R., Veblen, T.V., 2000. Rainfall variability, fire and vegetation dynamics in neotropical montane ecosystems in north-western Argentina. J. Biogeogr. 27, 1107-1121.

Grimaldi, M., Riéra, B., 2001. Geography and climate. In: Bongers, F., Charles-Dominique, P., Forget P.M., Théry, M. (Eds.), Nouragues: dynamics and plant-animal interactions in a neotropical rain forest. Kluwer, Dordrecht, pp. 9-18.

Hansen, A.J., Di Castri, F., 1992. Landscape boundaries: consequences for biotic diversity and ecological flows. Springer, Berlin.

Hemp, A., 2005. Climate change-driven forest fires marginalize the impact of ice cap wasting on Kilimanjaro. Global Change Biol. 11, 1013-1023.

Hemp, A., 2006. Continuum or zonation? Altitudinal gradients in the forest vegetation of Mt. Kilimandjaro. Plant Ecol. 184, 27-42.

Houle, G., Phillips, D.L., 1989. Seed availability and biotic interactions in granite outcrop plant communities. Ecology 70, 1307-1316.

Hurault, J.M., 1972. Français et Indiens en Guyane: 1604-1972. Union Générale d’Éditions, Paris.

Ibisch, P.L., Rauer, G., Rudolph, D., Barthlott, W., 1995. Floristic, biogeographical, and vegetational aspects of Pre-Cambrian rock outcrops (inselbergs) in eastern Bolivia. Flora 190, 299-314.

Ihaka, R., Gentleman, R., 1996. R: a language for data analysis and graphics. J. Comput. Graphical Stat. 5, 299-314. 
Kitayama, K., 1992. An altitudinal transect study of the vegetation of Mount Kinabalu, Borneo. Vegetatio $102,149-171$.

Kitayama, K., 1995. Biophysical conditions of the montane cloud forest of Mount Kinabalu, Sabah, Malaysia. In: Hamilton, L.S., Juvik, J.O., Scatena, F.N. (Eds.), Tropical montane cloud forests. Springer, Berlin, pp. 115-125.

Kitayama, K., Mueller-Dombois, D., 1994. An altitudinal transect analysis of the windward vegetation on Haleakala, a Hawaiian island mountain. II. Vegetation zonation. Phytocoenologia 24, 135-154.

Kounda-Kiki, C., Ponge, J.F., Mora, P., Sarthou, C., 2008. Humus profiles and successional development in a rock savanna (Nouragues inselberg, French Guiana): a micromorphological approach infers fire as a disturbance event. Pedobiologia 52, 85-95.

Kounda-Kiki, C., Vaçulik, A., Ponge, J.F., Sarthou, C., 2006. Humus profiles under main vegetation types in a rock savanna (Nouragues inselberg, French Guiana). Geoderma 136, 819-829.

Kupfer, J.A., Cairns, D.M., 1996. The suitability of montane ecotones as indicators of global climatic change. Prog. Physical Geogr. 20, 253-272.

Larpin, D., 1993. Les formations ligneuses sur un inselberg de Guyane Française: étude floristique, structurale et dynamique. PhD Thesis, Université Pierre et Marie Curie, Paris.

Larpin, D., 2001. The low forest (Nouragues inselberg). In: Bongers, F., Charles-Dominique, P., Forget, P.M., Théry, M. (Eds.), Nouragues: dynamics and plant-animal interactions in a neotropical rain forest. Kluwer, Dordrecht, pp. 47-63. 
Larpin, D., Sarthou, C., Tardy, C., 2000. Dynamique de la végétation sur l'inselberg des Nouragues (Guyane française) à différentes échelles de temps (annuelle à plurimillénaire). In: Servant, M., ServantVildary, S. (Eds.), Dynamique à long terme des écosystèmes forestiers intertropicaux. UNESCO, Paris, pp. 189-197.

Ledru, M.P., Blanc, P., Charles-Dominique, P., Fournier, M., Martin, L., Riéra, B., Tardy, C., 1997. Reconstitution palynologique de la forêt guyanaise au cours des 3000 dernières années. CR Acad. Sci. Paris Ser. 2 324, 469-476.

Legendre, P., Legendre, L., 1998. Numerical ecology, $2^{\text {nd }}$ English ed. Elsevier, Amsterdam.

Leps, J., Hadincova, V., 1992. How reliable are our vegetation analyses? J. Veg. Sci. 3, 119-124.

Malhi, Y., Wright, J., 2004. Spatial patterns and recent trends in the climate of tropical rain forest regions. Phil. Trans. R. Soc. London B 359, 311-329.

Martin, P.H., Sherman, R.E, Fahey, T.J., 2007. Tropical montane forest ecotones: climate gradients, natural disturbance, and vegetation zonation in the Cordillera Central, Dominican Republic. J. Biogeogr. 34, 1792-1806.

Neilson, R.P., 1991. Climatic constraints and issues of scale controlling regional biome. In: Holland, M.M., Risser, P.G., Naiman, R.J. (Eds.), Ecotones: the role of landscape boundaries in the management and restoration of changing environments. Chapman and Hall, London, pp. 31-55.

Oberrath, R., Böhning-Gaese, K., 2001. The signed Mantel test to cope with autocorrelation in comparative analyses. J. Appl. Stat. 28, 725-736.

Oumorou, M., Lejoly, J., 2003. Aperçu de la végétation de quelques inselbergs du Bénin. Syst. Geogr. Plants 
$73,215-236$.

Parmentier, I., Lejoly, J., Nguema, N., 2001. La végétation des inselbergs du monument naturel de Piedra Nzas (Guinée Equatoriale continentale). Acta Bot. Gallica 148, 341-365.

Parmentier, I., Müller, V., 2006. Grasslands and herbaceous fringes on inselbergs in Atlantic central Africa. Phytocoenologia 36, 565-597.

Parmentier, I., Stévart, T., Hardy, O., 2005. The inselberg flora of Atlantic Central Africa. I. Determinants of species assemblages. J. Biogeogr. 32, 685-696.

Poncy, O., Sabatier, D., Prévost, M.F., Hardy, I., 2001. The lowland high rainforest: structure and tree species diversity. In: Bongers, F., Charles-Dominique, P., Forget, P.M., Théry, M. (Eds.), Nouragues: dynamics and plant-animal interactions in a neotropical rain forest. Kluwer, Dordrecht, pp. 31-46.

Porembski, S., Barthlott, W., 2000. Inselbergs: biotic diversity of isolated rock outcrops in tropical and temperate regions. Springer, Berlin.

Poszwa, A., Dambrine, E., Ferry, B., Pollier, B., Loubet, M., 2002. Do deep tree roots provide nutrients to the tropical rain forest? Biogeochemistry 60, 97-118.

Pouvelle, S., Feer, F., Ponge, J.F., 2008. Topsoil as affected by dung deposition under resting places of red howler monkey (Alouatta seniculus). Pedosphere 18, 691-698.

Rascher, U., Lakatos, M., Büdel, B., Lüttge, U., 2003. Photosynthetic field capacity of cyanobacteria of a tropical inselberg of the Guiana Highlands. Eur. J. Phycol. 38, 247-256.

Riéra, B., 1995. Rôle des perturbations actuelles et passées dans la dynamique et la mosaïque forestière. Rev. 
Ecol. 50, 209-222.

Rosique, T., Pous, F., Charles-Dominique, P., 2000. Évolution morphométrique holocène d'un bassin versant de la forêt guyanaise: la Nourague occidentale (Guyane française). CR Acad. Sci. Paris Ser. 2 330, 333-340.

Sabatier, D., Grimaldi, M., Prévost, M.F., Guillaume, J., Godron, M., Dosso, M., Curmi, P., 1997. The influence of soil cover organization on the floristic and structural heterogeneity of a Guianan rain forest. Plant Ecol. 131, 81-108.

Sanz-Elorza, M., Dana, E.D., González, A., Sobrino, E., 2003. Changes in the high-mountain vegetation of the Central Iberian Peninsula as a probable sign of global warming. Ann. Bot. 92, 273-280.

Sarthou, C., 1992. Dynamique de la végétation pionnière sur un inselberg de la Guyane Française. PhD Thesis, Université Pierre et Marie Curie, Paris.

Sarthou, C., 2001. Plant communities on a granitic outcrop. In: Bongers, F., Charles-Dominique P., Forget P.M., Théry, M. (Eds.), Nouragues: dynamics and plant-animal interactions in a neotropical rain forest. Kluwer, Dordrecht, pp. 65-78.

Sarthou, C., Grimaldi, C., 1992. Mécanismes de colonisation par la végétation d'un inselberg granitique en Guyane française. Rev. Ecol. 47, 329-349.

Sarthou, C., Kounda-Kiki, C., Vaçulik, A., Mora, P., Ponge, J.F., 2009. Successional patterns on tropical inselbergs: a case study on the Nouragues inselberg (French Guiana). Flora 204, 396-407.

Sarthou, C., Villiers, J.F., 1998. Epilithic plant communities on inselbergs in French Guiana. J. Veg. Sci. 9, 847-860. 
Sarthou, C., Villiers, J.F., Ponge, J.F., 2003. Shrub vegetation on tropical granitic inselbergs in French Guiana. J. Veg. Sci. 14, 645-652.

Sheil, D., Burslem, D.F.R.P., 2003. Disturbing hypotheses in tropical forests. TREE 18, 18-26.

Sherman, R.E, Martin, P.H., Fahey, T.J., Degloria, S.D., 2008. Fire and vegetation dynamics in high elevation neotropical montane forests of Dominican Republic. Ambio 37, 535-541.

Théveniaut, H., Delor, C., 2004. Connaissance géologique de la Guyane. BRGM, Orléans.

Vázquez, J.A., Givnish, T.J., 1998. Altitudinal gradients in tropical forest composition, structure, and diversity in the Sierra de Manantlán. J. Ecol. 86, 999-1020.

Viereck, L.A., Dyrness, C.T., Foote, M.J., 1993. An overview of the vegetation and soils of the floodplain ecosystems of the Tanana River, interior Alaska. Can. J. For. Res. 23, 889-898.

Withers, P.C., 2000. Overview of granite outcrops in Western Australia. J. R. Soc. Western Australia 83, 103108.

Woldu, Z., Feoli, E., Nigatu, L., 1989. Partitioning an elevation gradient of vegetation from southeastern Ethiopia by probabilistic methods. Vegetatio 81, 189-198. 


\section{Figure legends}

Figure 1. Sketch map of the Nouragues inselberg, with indication of the three transects studied in 1995 and 2005. The dotted zone shows the area covered by rock savanna. Other areas are covered by closed forest (low forest and tall-tree rain forest)

Figure 2. Sketch diagram of the passage from the rock savanna to the low forest, showing the distribution of main plant growth forms and soil conditions along transects lines. Oblique lines indicate the presence of mineral soil above granite

Figure 3. Principal Components Analysis (PCA). Projection of (a) additional (passive) variables and (b) samples (quadrats) in the plane of the first two principal components

Figure 4. Variation of F1 values (PCA coordinates of the first component) according to the distance of samples (quadrats) to the start of each transect in 1995 and 2005 (scale in meters). Positive values indicate that the quadrat pertains to Community I while negative values indicate that the quadrat pertains to Community II. The depth of the mineral soil (down to $70 \mathrm{~cm}$ ), measured in 2005, is indicated along the abscissa at the lower part of each chart

Figure 5. Principal Components Analysis (PCA). Projection of plant species (a), represented by three-letter codes (according to Appendices 1 and 2) or by their traits: growth forms (b), fruit types (c), dispersal types (d), functional types (e), seed sizes (f) in the plane of the first two principal components of PCA

Figure 6. Cluster analysis. Similarity tree among plant species. Species codes according to Appendices 1 and 2. Bold type (versus unbold type) indicates species displaying positive (versus negative, respectively) coordinates along the first principal component of PCA. Roman type (versus italic type) indicates species displaying positive (versus negative, respectively) coordinates along the second principal 
components of PCA 


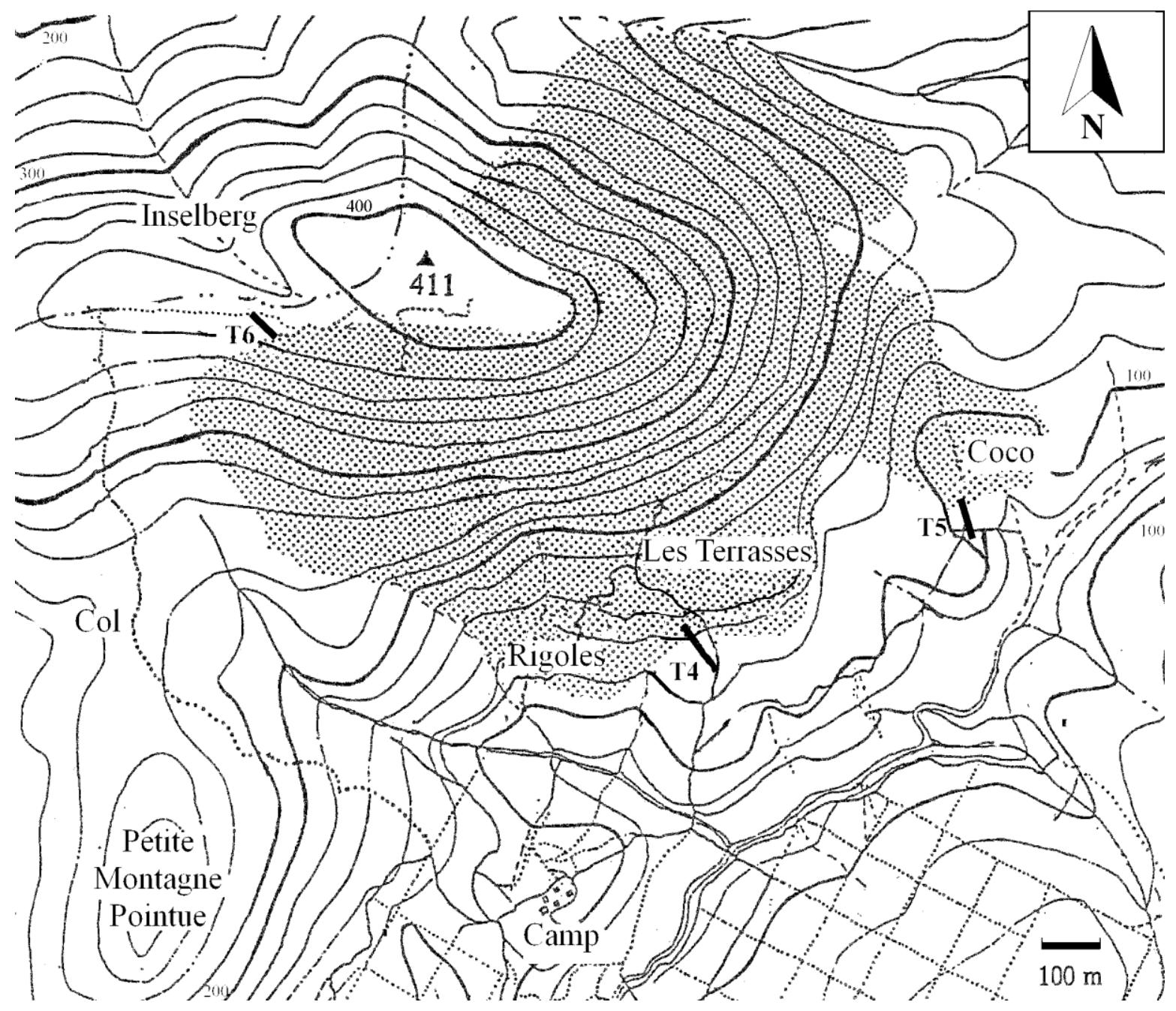

Fig. 1 


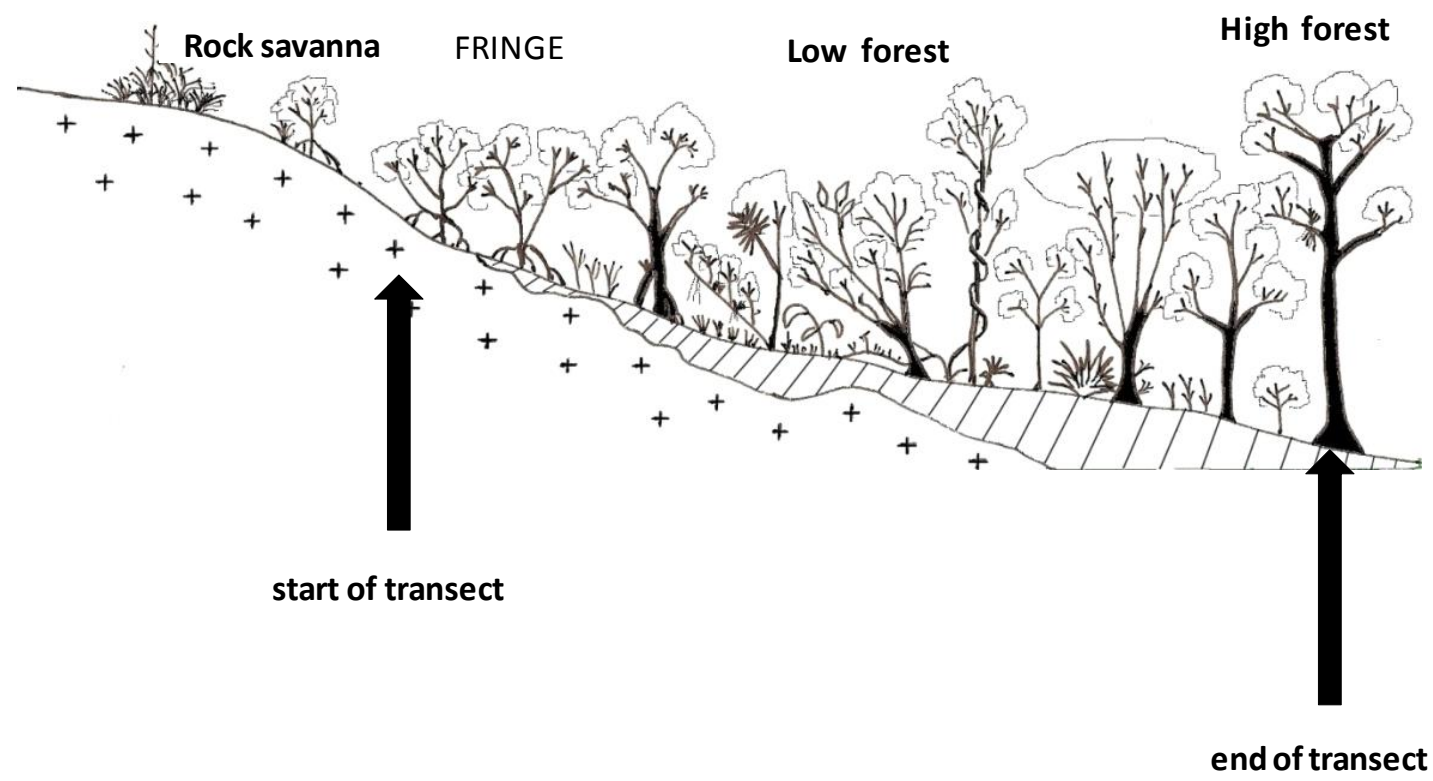

Fig. 2 

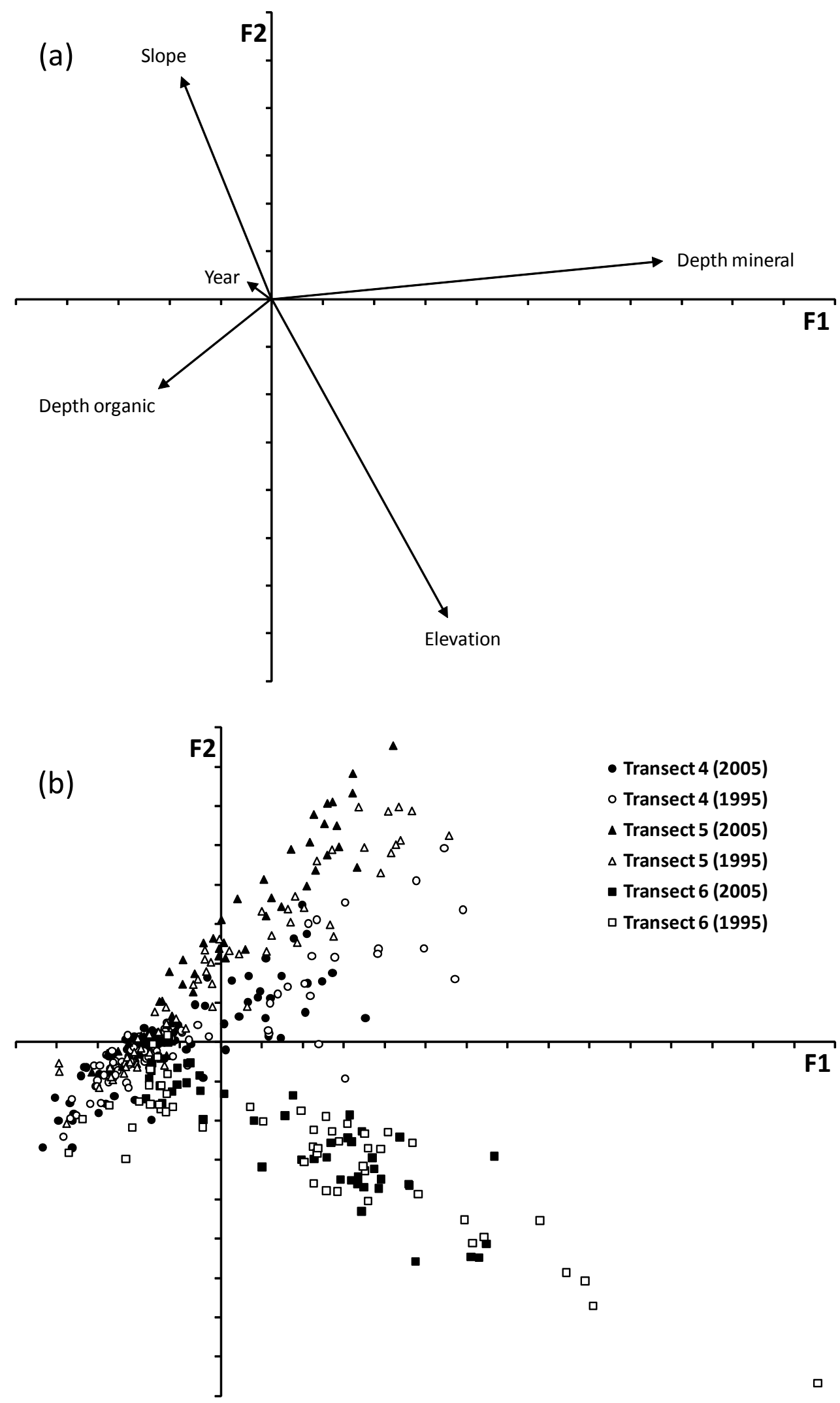

Fig. 3 

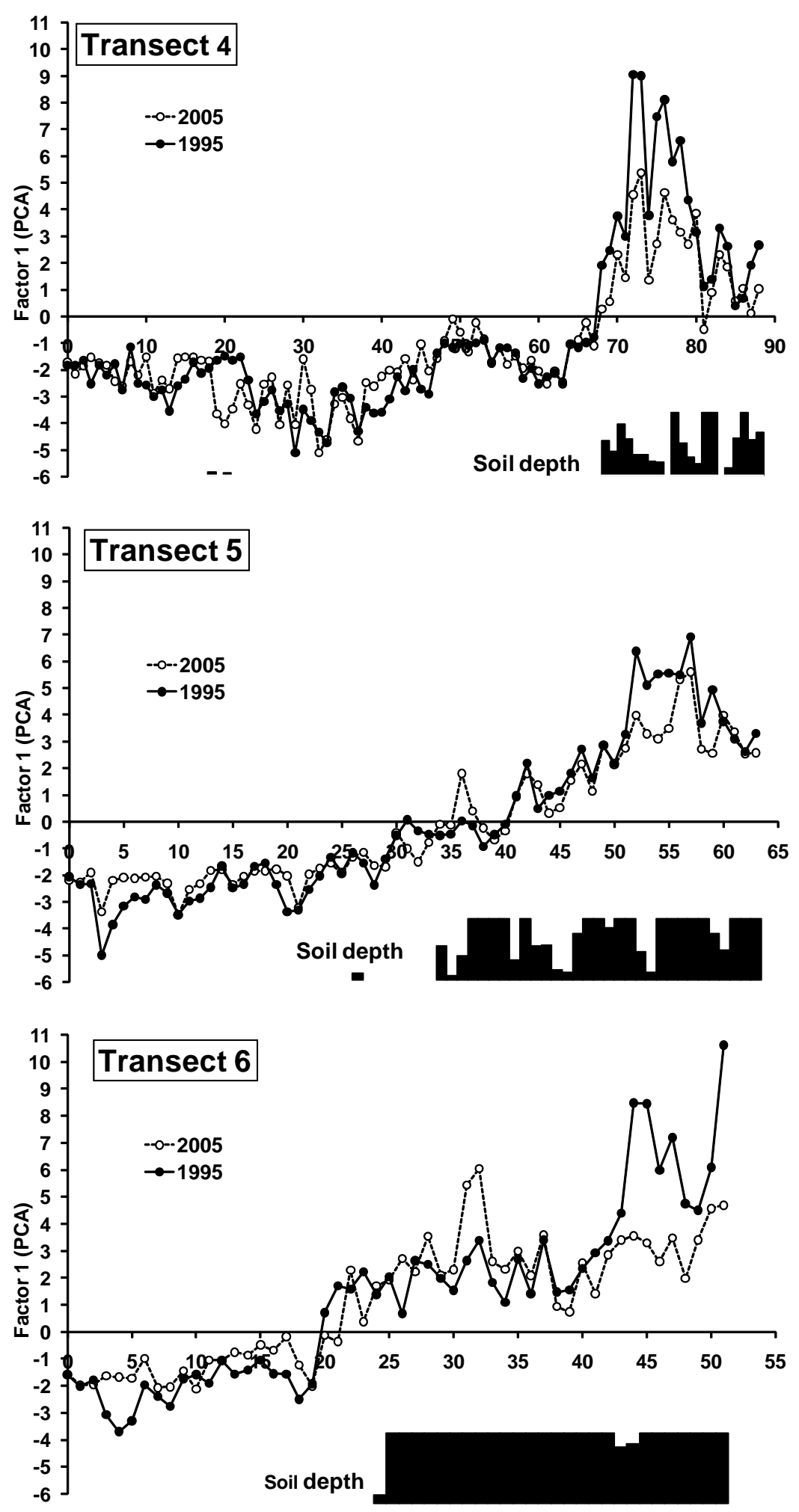

Fig. 4 

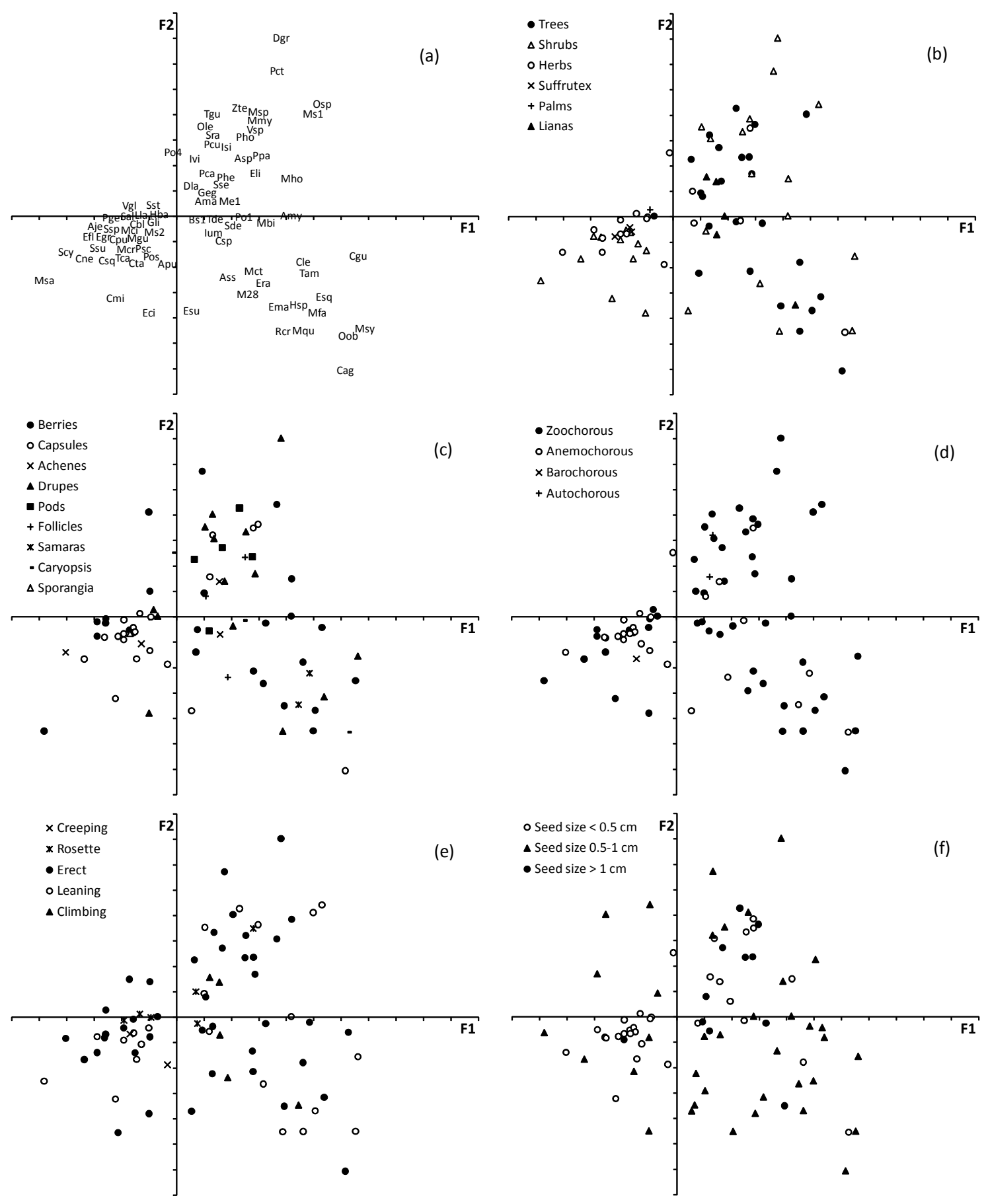

Fig. 5 


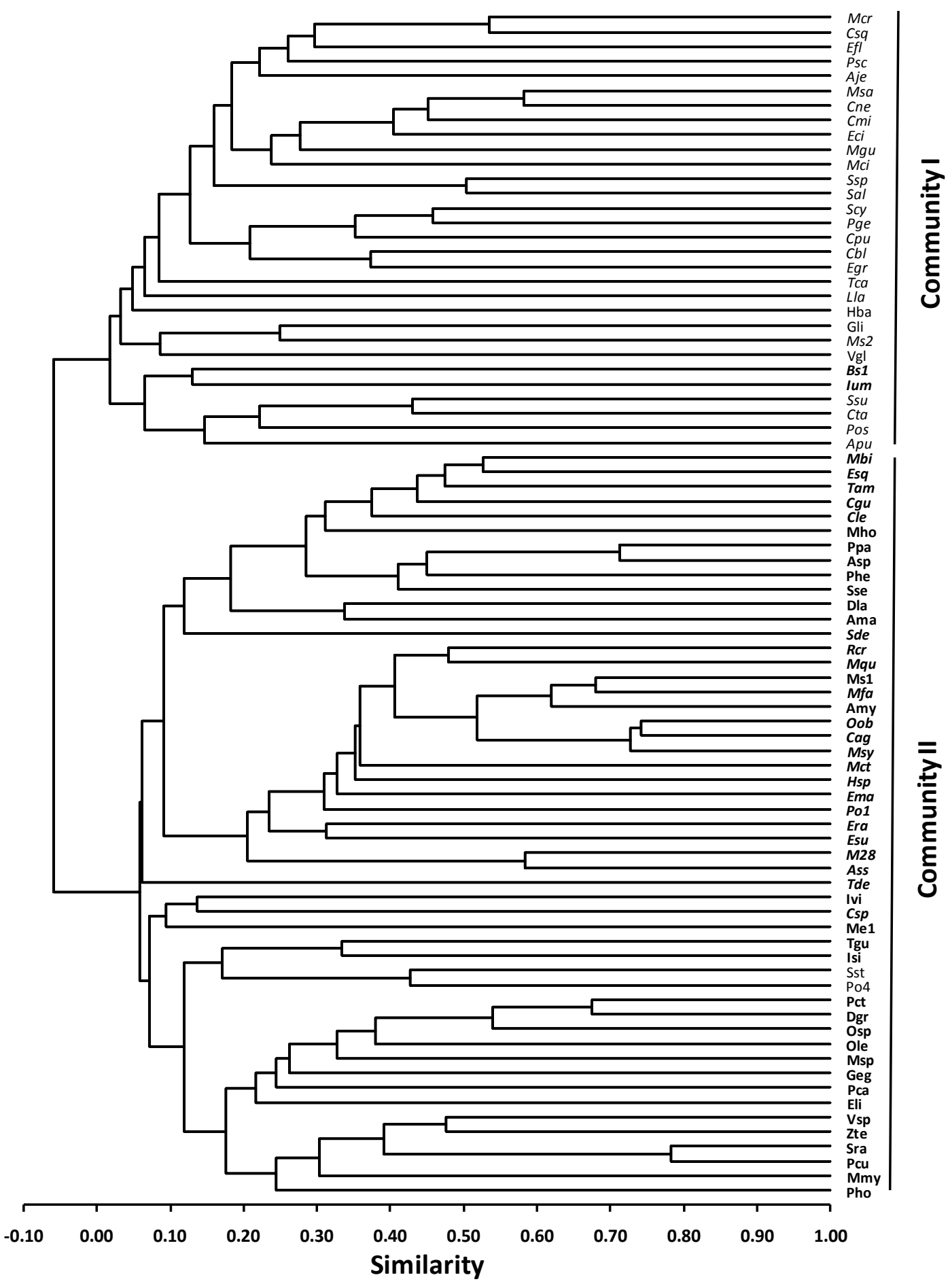

Fig. 6 
Table 1. Mantel correlation tests at quadrat scale with and without distance as co-variate. ${ }^{* \star *}=P<0.0002$

\begin{tabular}{|c|c|c|c|}
\hline & Transect 4 & Transect 5 & Transect 6 \\
\hline Plant species richness vs Dominant canopy height & $0.33^{\star \star *}\left(0.26^{\star * *}\right)$ & $0.39^{\star * \star}\left(0.11^{\star * \star}\right)$ & $0.53^{\star * \star}\left(0.25^{\star * *}\right)$ \\
\hline Principal component F1 (PCA) vs Depth of mineral soil & $0.57^{\star \star \star}\left(0.27^{\star \star \star}\right)$ & $0.81^{\star * \star}\left(0.31^{\star \star \star}\right)$ & $0.86^{\star \star \star}\left(0.47^{\star \star \star}\right)$ \\
\hline
\end{tabular}


Table 2. Changes in the mean distance $(\mathrm{m})$ of plant species from start of transect between 1995 and 2005. Between-year differences were tested by paired Student's $t$ test. ${ }^{*}=\mathrm{P}<0.05$; ${ }^{\star *}=\mathrm{P}<0.01$

\begin{tabular}{llllll}
\hline & & Transect 4 & Transect 5 & Transect 6 $\begin{array}{l}\text { Observed t value } \\
\text { (2005 vs 1995) }\end{array}$ \\
\hline All species & 1995 & 55.5 & 36.9 & 30.1 & \\
& 2005 & 53.9 & 35.4 & 28.7 & $-26.0^{* *}$ \\
Trees and shrubs & 1995 & 58.2 & 38.1 & 30.6 & \\
& 2005 & 57.0 & 36.6 & 29.5 & $-13.7^{* *}$ \\
Herbs and suffrutex & 1995 & 44 & 30.3 & 26 & \\
& 2005 & 40.5 & 28.8 & 23.2 & $-4.3^{\star}$ \\
\hline
\end{tabular}


Appendix 1. List of species names and codes of trees and shrubs found in the three studied transects. Stars indicate taxa which were included in PCA and cluster analysis (present in at

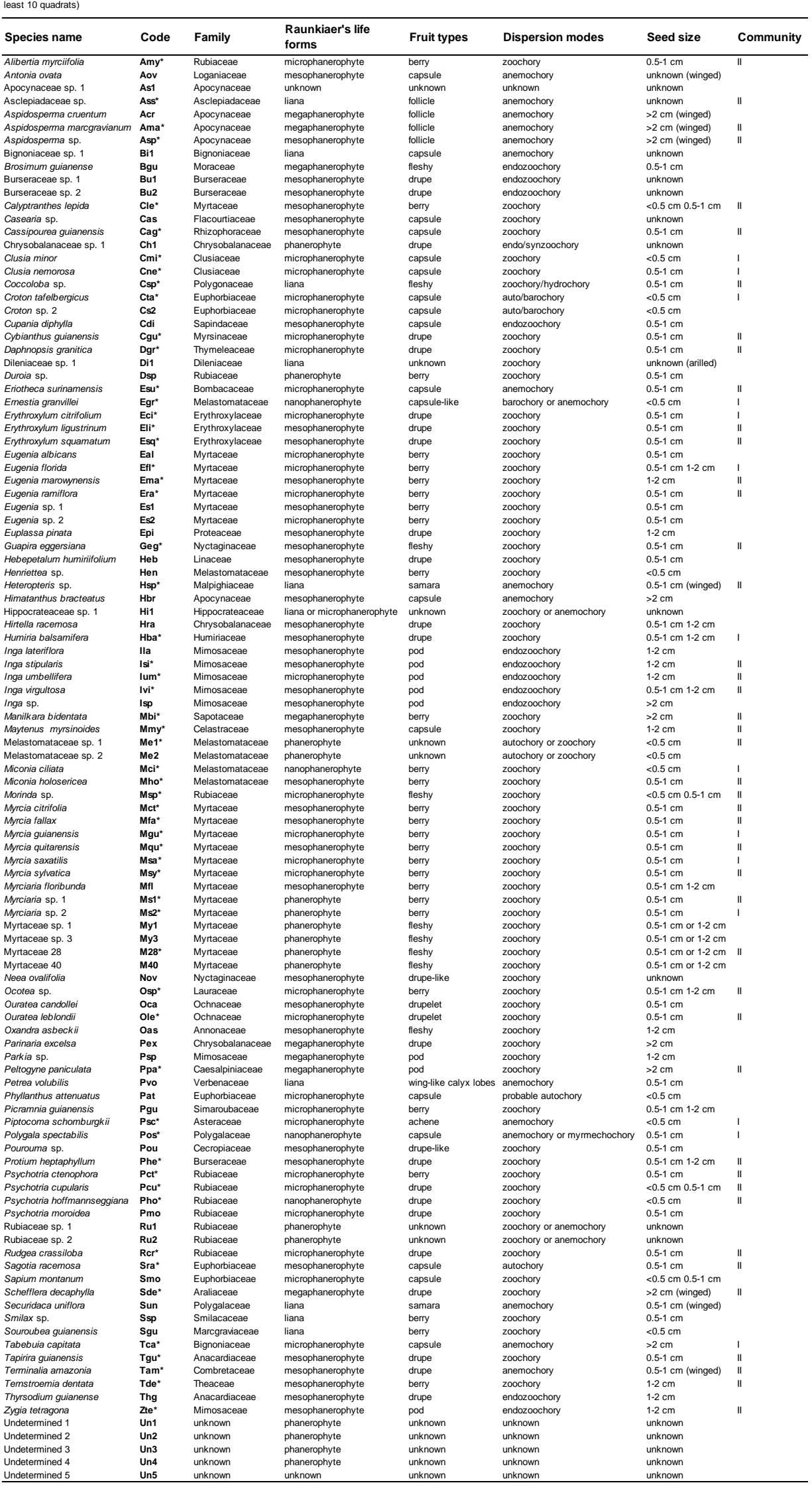


Appendix 2. List of species names and codes of herbs and suffrutx specues found in the three studied transects. Stars indicate taxa which were included in PCA and cluster analysis (present in at least 10 quadrats)

\begin{tabular}{|c|c|c|c|c|c|c|c|}
\hline Species name & Code & Family & $\begin{array}{l}\text { Raunkiaer's life } \\
\text { forms }\end{array}$ & Fruit types & Dispersion modes & Seed size & Community \\
\hline Aechmea melinonii & Ame & Bromeliaceae & hemicryptophyte & berry & zoochory & $<0.5 \mathrm{~cm} \mathrm{0.5-1 \textrm {cm }}$ & \\
\hline Aganisia pulchella & $\mathrm{Apu}^{*}$ & Orchidaceae & hemicryptophyte & capsule & anemochory & $<0.5 \mathrm{~cm}$ & 1 \\
\hline Anthurium jenmanii & $\mathrm{Aje}^{\star}$ & Araceae & hemicryptophyte & berry & zoochory & $<0.5 \mathrm{~cm}$ & 1 \\
\hline Bromelia sp. 1 & Bs1 $^{*}$ & Bromeliaceae & hemicryptophyte & berry & zoochory & $<0.5 \mathrm{~cm} 0.5-1 \mathrm{~cm}$ & ॥ \\
\hline Calathea squarrosa & Csq $^{*}$ & Marantaceae & geophyte & berry & zoochory or myrmechory & $0.5-1 \mathrm{~cm} 1-2 \mathrm{~cm}$ & 1 \\
\hline Chamaecrista desvauxii & Cde & Fabaceae & chamaephyte & pod & anemochory & $<0.5 \mathrm{~cm}$ & \\
\hline Chelonanthus purpurascens & $\mathrm{Cpu}^{*}$ & Gentianaceae & hemicryptophyte & capsule & anemochory & $<0.5 \mathrm{~cm}$ & 1 \\
\hline Cleistes rosea & Cro & Orchidaceae & therophyte & capsule & anemochory & $<0.5 \mathrm{~cm}$ & \\
\hline Cuphea blackii & $\mathrm{Cb}^{*}$ & Lythraceae & chamaephyte & capsule & anemochory & $<0.5 \mathrm{~cm}$ & 1 \\
\hline Cyperaceae sp. 1 & Cy1 & Cyperaceae & hemicryptophyte & achene & autochory or anemochory & $<0.5 \mathrm{~cm}$ & \\
\hline Disteganthus lateralis & $\mathrm{Dla}^{*}$ & Bromeliaceae & hemicryptophyte & berry & zoochory & $0.5-1 \mathrm{~cm}$ & $\|$ \\
\hline Elleanthus brasiliensis & Ebr & Orchidaceae & hemicryptophyte & capsule & anemochory & $<0.5 \mathrm{~cm}$ & \\
\hline Encyclia ionosma & Eio & Orchidaceae & hemicryptophyte & capsule & anemochory & $<0.5 \mathrm{~cm}$ & \\
\hline Episcia sphalera & Esp & Gesneriaceae & hemicryptophyte & capsule & autochory & $<0.5 \mathrm{~cm}$ & \\
\hline Guzmania lingulata & $\mathrm{Gli}^{*}$ & Bromeliaceae & hemicryptophyte & capsule & anemochory & $<0.5 \mathrm{~cm}$ & 1 \\
\hline Ichnanthus nemoralis & Ine & Poaceae & hemicryptophyte & caryopsis & anemochory & $<0.5 \mathrm{~cm}$ & \\
\hline Jessenia bataua & Jba & Arecaceae & microphanerophyte & drupe & barochory or zoochory & $>2 \mathrm{~cm}$ & \\
\hline Lindsaea sp. & Lsp & Dennstaedtiaceae & hemicryptophyte & sporangium & anemochory & $<0.5 \mathrm{~cm}$ & \\
\hline Ludovia lancifolia & $\mathrm{Lla}^{*}$ & Cyclanthaceae & hemicryptophyte & berry & zoochory & $<0.5 \mathrm{~cm}$ & 1 \\
\hline Macrocentrum cristatum & Mcr* & Melastomataceae & chamaephyte & capsule & anemochory & $<0.5 \mathrm{~cm}$ & 1 \\
\hline Olyra obliquifolia & Oob* & Poaceae & hemicryptophyte & caryopsis & anemochory & $<0.5 \mathrm{~cm}$ & $\|$ \\
\hline Paradrymonia campostyla & $\mathrm{Pac}$ & Gesneriaceae & liana & capsule & autochory & $<0.5 \mathrm{~cm}$ & \\
\hline Pariana campestris & $\mathrm{Pca}^{*}$ & Poaceae & hemicryptophyte & caryopsis & anemochory & $<0.5 \mathrm{~cm}$ & $\|$ \\
\hline Phramipedium lindleyanum & $\mathrm{Phl}$ & Orchidaceae & hemicryptophyte & capsule & anemochory & $<0.5 \mathrm{~cm}$ & \\
\hline Pitcairnia geyskesii & $\mathrm{Pge}^{\star}$ & Bromeliaceae & hemicryptophyte & capsule & anemochory & $<0.5 \mathrm{~cm}$ (winged) & 1 \\
\hline Poaceae sp. 1 & Po1* & Poaceae & hemicryptophyte & caryopsis & anemochory & $<0.5 \mathrm{~cm}$ & ॥ \\
\hline Poaceae sp. 2 & Po2 & Poaceae & hemicryptophyte & caryopsis & anemochory & $<0.5 \mathrm{~cm}$ & \\
\hline Poaceae sp. 3 & Po3 & Poaceae & hemicryptophyte & caryopsis & anemochory & $<0.5 \mathrm{~cm}$ & \\
\hline Poaceae sp. 4 & $\mathrm{Po}^{*}$ & Poaceae & hemicryptophyte & caryopsis & anemochory & $<0.5 \mathrm{~cm}$ & I \\
\hline Poaceae sp. 5 & Po5 & Poaceae & hemicryptophyte & caryopsis & anemochory & $<0.5 \mathrm{~cm}$ & \\
\hline Sauvagesia aliciae & $\mathrm{Sal}^{*}$ & Ochnaceae & chamaephyte & capsule & anemochory & $<0.5 \mathrm{~cm}$ & 1 \\
\hline Scleria cyperina & Scy* & Cyperaceae & hemicryptophyte & achene & anemochory & $<0.5 \mathrm{~cm}$ & 1 \\
\hline Scleria secans & Sse ${ }^{*}$ & Cyperaceae & liana & achene & anemochory & $<0.5 \mathrm{~cm}$ & $\|$ \\
\hline Selaginella sp. & Ssp* & Selaginellaceae & hemipcryptophyte & sporangium & anemochory & $<0.5 \mathrm{~cm}$ & I \\
\hline Stelestylis surinamensis & $\mathrm{Ssu}^{*}$ & Cyclanthaceae & hemicryptophyte & berry & zoochory & $<0.5 \mathrm{~cm}$ & I \\
\hline Stylosanthes guianensis & $\mathrm{Sgu}$ & Fabaceae & chamaephyte & pod & anemochory & $<0.5 \mathrm{~cm}$ & \\
\hline Syagrus stratincola & Sst $^{\star}$ & Arecaceae & micro-mesophanerophyte & drupe & zoochory & $>2 \mathrm{~cm}$ & 1 \\
\hline Vanilla ovata & Vov & Orchidaceae & liana & capsule & anemochory & $<0.5 \mathrm{~cm}$ & \\
\hline Vriesea gladioliflora & $\mathbf{V g} \mathbf{k}^{*}$ & Bromeliaceae & hemicryptophyte & capsule & anemochory & 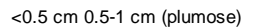 & I \\
\hline Vriesea pleiostica & $\mathrm{Vpl}$ & Bromeliaceae & hemicryptophyte & capsule & anemochory & 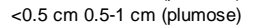 & \\
\hline Vriesea splendens & Vsp* & Bromeliaceae & hemicryptophyte & capsule & anemochory & $<0.5 \mathrm{~cm} 0.5-1 \mathrm{~cm}$ (plumose) & $\|$ \\
\hline
\end{tabular}

